\title{
Iron, zinc and iodide status in Mexican children under 12 years and women $12-49$ years of age. A probabilistic national survey
}

Salvador Villalpando, MD, PhD, ${ }^{(1)}$ Armando G arcía-G uerra, MSc, ${ }^{(1)}$ Claudia Ivo nne Ramírez-Silva, BSc, ${ }_{1}^{(1)}$ Fabiola Mejía-Rodríguez, BSc, ${ }^{(1)}$ G uadalupe Matute, C hem, ${ }^{(2)}$ Teresa Shamah-Levy, MSC, ${ }^{(1)}$ Juan A Rivera, MS, PhD. ${ }^{(1)}$

\begin{abstract}
Villalpando S, García-GuerraA, Ramírez-Silva CI, Mejía-Rodríguez F, Matute G, Shamah-LevyT, Rivera JA. Iron, zinc and iodide status in Mexican children under 12 years and women $12-49$ years of age. A probabilistic national survey. Salud Publica Mex 2003;45 suppl 4:S520-S529. The English version of this paper is available too at: http://www.insp.mx/salud/index.html
\end{abstract}

\begin{abstract}
A bstract
Objective. To describe the epidemiology of iron, zinc and iodide deficiencies in a probabilistic sample of Mexican women and children and explore its association with some dietary and socio-demographic variables. Material and Methods We carried out in 1999 an epidemiological description of iron (percent transferrin saturation, PTS, $<16 \%$ ), serum zinc $(<65 \mathrm{ug} / \mathrm{dl})$ and iodide $(<50 \mathrm{ug} / \mathrm{l}$ urine) deficiencies in a probabilistic sample of 1,363 Mexican children under 12 years and of 731 women of child-bearing age. Serum iron,Total Iron Binding Capacity (TIBC) and zinc were measured by atomic absorption spectrometry, and urinary iodide by a colorimetric method. Logistic regression models explored determinants for such micromineral deficiencies. Results. Iron deficiency was higher (67\%) in infants $<2$ years of age. Prevalence declined (34-39\%) at school age. The prevalence for iron deficiency in women was $40 \%$. Z inc deficiency was higher in infants $<2$ years of age (34\%) than in school-age children (19-24\%). Prevalence in women was 30\%, with no rural/urban difference. In women the likelihood of iron deficiency decreased as SEL improved $(p=0.04)$ and increased with the intake of cereals $(p=0.01)$. The likelihood of low serum zinc levels was greater in women and children of low socio economic level (SEL) $(p<0.02$ and $p=0.001)$ io dide deficiency was negligible in both children and women. Conclusions. The data shows high prevalence of iron deficiencyspecially in infants 12 to 24 months of age. It is suggested that
\end{abstract}

\author{
Villalpando S, García-Guerra A, Ramírez-Silva CI, Mejía- \\ Rodríguez F, Matute G, Shamah-LevyT, Rivera JA. \\ Estado de hierro, zinc y yodo en niños menores \\ de 12 años y en mujeres de 12-49 años de edad \\ en México. Una encuesta probabilística nacional. \\ Salud Publica Mex 2003,45 supl 4:S520-S529. \\ El texto completo en inglés de este artículo también \\ está disponible en: http://www.insp.mx/salud/index.html
}

\section{Resumen}

Objetivo. Describir la epidemiología de las deficiencias de hierro, zinc y yodo en una muestra probabilística de mujeres y niños mexicanos y analizar algunas asociaciones con factores dietéticos y sociodemográficos. Material y métodos Descripción epidemiológica de las deficiencias de hierro (Porcentaje de saturación de transferrina $<16 \%)$, zinc $(<65 \mathrm{ug} / \mathrm{dl})$ y yodo (<50ug/l orina) en una muestra probabilística de 1363 niños y 731 mujeres. Las concentraciones séricas de hierro, y la capacidad total de saturación de hierro y zinc se midieron por espectrometría de abso rción atómica, y el yodo por un método colorimétrico. Los determinantes de tales deficiencias se estudiaron mediante modelos de regresión logística. Resultados. La deficiencia de hierro fue mayor (67\%) en niños $<2$ años de edad. La prevalencia disminuyó en los escolares (34-39\%). La prevalencia de deficiencia de hierro en mujeres fue de $40 \%$. La deficiencia de zinc fue mayor en niños <2 años de edad (34\%) que en escolares (19-24\%). La prevalencia en mujeres fue de $30 \%$, sin diferencia rural/urbana. La probabilidad de tener deficiencia de hierro en mujeres disminuyó con el nivel socio-económico $(p=0.04)$ y aumentó con la ingestión de cereales $(p=0.01$ ). La probabilidad de tener concentraciones bajas de zinc sérico fueron mayores en mujeres de nivel socioeconómico (SES) bajo $(p=0.02$ y $p=0.001)$. La prevalencia de deficiencia de yodo fue casi inexistente tanto en niños como en mujeres. Conclusiones. Los datos demuestran una alta prevalencia de de-

(1) Centro de Investigación en N utrición y Salud, Instituto N acional de Salud Pública, Cuernavaca Morelos, México.

(2) Unidad de Investigación en N utrición, Centro Médico N acional, Instituto Mexicano del Seguro Social, México, DF, México.

Received on: August 20,2002 - Accepted on: 0 cto ber 16, 2003

Solicitud de sobretiros: D r. Salvador Villalpando. A venida Universidad 655, Colonia Santa María A huacatitlán 62508 Cuernavaca Morelos, México. E-mail: svillalp@ insp.mx 
in older children and women 12 to 49 years of age that iron bioavailability is low. The prevalence of zinc deficiency was also very high. The English version of this paper is available to 0 at: http://www.insp.mx/salud/index.html

Key words:iron deficiency; zinc deficiency; iodide deficiency; preschoolers; school-age children; women of child-bearing age; Mexico ficiencia de hierro, especialmente en niños de 12 a 24 meses de edad. Se sugiere que en niños mayores y en mujeres de 12 49 años existe una baja biodisponibilidad de hierro. La deficiencia de zinc fue tambien muy alta. El texto completo en inglés de este artículo también está disponible en: http:// www.insp.mx/salud/index.html

Palabras clave: deficiencia de hierro; deficiencia de zinc; deficiencia de yodo; niños preescolares; niños escolares; mujeres en edad reproductiva; México ron deficiency is the most common nutritional deficiency worldwide. Although, anemia is the best-known consequence of iron deficiency, it also produces impairments in mental development, in the ability to combat infections when occurring during early childhood, and difficulty in performance of physical work in later life. ${ }^{1}$ Mild zinc deficiency is associated with growth retardation; it also alters the immune response, and increases de incidence of diarrhea and other infections. ${ }^{2,3}$

Ample information on the prevalence of stunting in Mexico is available. ${ }^{4,6}$ However, assessment of the nutritional status of micronutrients of Mexican populations is contained in a handful of studies, most of which are not nationally or regionally representative. ${ }^{8-10}$ Information about the prevalence of micronutrient deficiencies is of utmost relevance for the design and implementation of public nutrition programs.

This study describes the epidemiology of iron, zinc and iodide deficiencies, based on determinations of their concentrations in biological samples from a probabilistic sample of Mexican children under twelve and women 12-49 years of age. Also, it explores the associations between these microminerals and dietary and socio-demographic variables that may play a role as determinants.

\section{Material and Methods}

Data were extracted from the database of the Mexican National Nutrition Survey of 1999 (ENN-99). The methodology of this probabilistic survey was published in detail elsewhere. ${ }^{6}$ Briefly, the sampling procedure included a randomized selection of households based on the master household frame provided by Instituto Nacional de Estadistica, Geografía e Informática (INEGI). Blood and urine samples were obtained in subsamples of children under 12 and women 12-49 years of age, by drafting $6.6 \%$ of the 21000 households originally selected.

The probability of selecting a given household (V) to obtain blood samples from an individual of one age group (w) was determined by the following formula:

$$
\operatorname{PS}\left(V_{W}\right)=\operatorname{PD}\left(V_{W}\right) \cdot \frac{S}{Q}
$$

After prevalences were calculated, they were expanded to represent the original population.

The expansion factors were calculated based on the characteristics of the Mexican population in 1995 according to census data published by Instituto Nacional de Estadística Geografía e Informática (INEGI).

Files of children under 12 and women 12 to 49 years of age containing information about their serum iron, zinc and urine iodide concentrations, birth date, gender, maternal education, dietary intake, socioeconomic level (SEL), ethnic origin, consumption of dietary supplements, and if they were beneficiaries of a food assistance program (BFAP) were selected for the present analysis. Maternal education was stratified into five categories based on the education cycles completed: no schooling, primary school (6 years), secondary school (9 years), high school or more ( $>12$ years). Socioeconomic level was a continuous variable using a construct based on a principal components analysis of household possessions and characteristics. Ethnic origin was categorized as indigenous for families in which at least one member spoke a native language. ${ }^{10}$ Dietary supplements included vitamins and/or minerals (pills, drops, etc.), or enriched food provided within a formal public nutrition intervention. Food assistance was considered as present when the family or the study subject were beneficiaries of any program providing food in kind or at subsidized prices. Food assistance programs included in the questionnaire were: Fidelist, 
distributing tortillas and Liconsa, distributing milk, both at subsidized prices; and DIF (Desarrollo Integral de la Familia [Integral development of the family]), distributing free food baskets. PROGRESA (Programa de educación salud y alimentación [Education, health and nutrition program]) was not included because at the time of the survey distribution of fortified food was just starting.

\section{Study design}

Chronological age of children was divided into oneyear intervals. Women were categorized as pregnant and non-pregnant. Subjects were categorized as rural if they lived in a community of less than 2,500 inhabitants; all others were categorized as urban. The country was divided arbitrarily into four geographic regions: the North region included the states of Baja California, South Baja California, Coahuila, Chihuahua, Durango, Nuevo León, Sonora and Tamaulipas. The Center included the states of Aguascalientes, Colima, Guanajuato, Jalisco, México, Michoacán, Morelos, Nayarit, Querétaro, San Luis Potosí, Sinaloa and Zacatecas. The Mexico City region included the Federal District and the nearby urban areas. The South region included the states of Campeche, Chiapas, Guerrero, Hidalgo, Oaxaca, Puebla, Quintana Roo, Tabasco, Tlaxcala, Veracruz and Yucatán.

\section{Blood sample collection, preparation and preservation}

Blood samples were drawn from a vein in the forearm, in evacuated glass tubes specially prepared for trace elements (vacutainer, purple cap, evacuated tubes, Beckton Dickinson Inc, Lakes, NJ, USA). Serum was immediately separated on the household premises using a portable centrifuge EB8 (Hettich, Tuttlingen, Germany), and transferred into cryovials and preserved in liquid nitrogen until delivered to a central laboratory. Although they were spot samples, more than $80 \%$ were collected in the morning after at least two hours of fasting. Subjects with evident signs of acute infections or other debilitating illnesses were not included in the sample.

\section{Methods for iron, zinc, iodide, C-reactive protein determinations.}

The concentrations of iron, total iron binding capacity (TIBC), and zinc and C-reactive protein were determined in serum samples, and iodide was determined in spot urine samples.
Iron status. Serum iron and TIBC were estimated by determining iron concentrations before and after incubating a serum aliquot with saturated iron solution and then precipitating it with trichloroacetic acid. Determinations were made by atomic absorption spectrometry using an Analyst 300 spectrometer (Perkin-Elmer, Norwalk, Ct, USA). Percent transferrin saturation (PTS) was calculated dividing serum iron by TIBC, times $100 .{ }^{11,12}$ Because PTS is a more parsimonious indicator of iron status than the other two measurements, it was used in this research as the sole indicator of iron status. Iron status as indicated by PTS was graded into the following categories: Normal: $>20 \%$; iron depletion: $16.1-20 \%$; and iron deficiency: $<16 \%{ }^{13}$

Serum Zinc. Serum zinc concentrations were determined by atomic absorption spectrometry using the same instrument described for the determinations of iron..$^{14} \mathrm{~A}$ cut-off value of $70 \mathrm{ug} / \mathrm{dl}$ has been recommended ${ }^{15}$ to assess zinc deficiency in children based on NHAENES II results. Because blood samples in this survey were not obtained necessarily after fasting, we used a cut-off value of $65 \mathrm{ug} / \mathrm{dl}$, as recommended by the International Zinc Nutrition Consultative Group (IzincCG).

C-reactive protein. C-reactive protein was determined by nephelometry using a commercial kit (Dade-Behring, Marburg, Germany). The cut-off point used to detect abnormal values was $>3 \mathrm{mg} / \mathrm{dl}$, as suggested by the manufacturer.

Urinary iodide. Iodide concentrations were measured in the urine samples collected in hermetic cryovial and frozen at $-70^{\circ} \mathrm{C}$, until determination by a colorimetric method, based on the capacity of iodide to reduce ceric-amonium sulfate in the presence of arseniosus acid. The urine sample was digested previously with ammonium persulfate. ${ }^{16}$

Cut-off concentrations of iodide to define deficiencies were those of ICCIDD/OMS/OPS/UNICEF ${ }^{17}$ i.e., normal: > $100 \mathrm{ug} / \mathrm{l}$, low risk: $50-99 \mathrm{ug} / \mathrm{l}$, moderate risk: 20-49 ug/l, and high risk: $<20 \mathrm{ug} / 1$.

\section{A ssessment of dietary intake}

Dietary intake was assessed by a single 24-hour (24-h) recall applied to the women. The dietary intake of children was assessed by 24-h recall applied to the mother. Based on this single recall the consumption of food and nutrients was calculated. Nutrient intake was calculated by multiplying the portion size in grams of a given food by the nutrient content per gram of that food as per food-composition tables. Food composition was obtained from a data base which included micronutrient information from 7 published food composition tables $^{18-23}$ and from an unpublished composition table 
(Información Nutricional de Marinela, Marinela Company, Mexico City), all of which were pooled at the Instituto Nacional de Salud Pública, Mexico.

\section{Data analysis}

Description of variables was made by central tendency and dispersion statistics. The prevalence of each category of nutritional status of minerals included in this analysis is presented as rates and confidence intervals. The presence of a positive C-reactive protein determination $(>3 \mathrm{mg} / \mathrm{dl})$ excluded iron and zinc values of that individual from the analysis. Actual sample size for any category presented here was expanded using a population factor as described above.

Also, to identify potential predictors of the nutritional status for each mineral, we constructed logistic regression models, which controlled for the clustered design of the study. Individual minerals were coded as normal or abnormal according to the following cut-off values: PTS< $20 \%$ and serum zinc $<65 \mathrm{ug} / \mathrm{dl}$, and introduced into the models as dependent variables. Age, gender, socioeconomic level, ethnic status, receiving food assistance programs, and the daily intake of the following food groups: cereals, meat, legumes, were introduced as independent variables. Food intake was expressed as portions of 100 grams consumed per day. Because of the great co-linearity between socioeconomic level, maternal education and height we choose include socioeconomic level in the model, and not maternal education, height or height/age. There are some difficulties in explaining the association of nutritional status of micronutrients and dietary variables, because the latter are frequently associated with SEL. Controlling for SEL when examining associations with diet may represent over controlling. Thus, to avoid it we constructed two additional restricted models in which only socioeconomic variables or dietary variables were alternately introduced as independent variables.

Data entry was done using a Clipper-based program using data entry formats that included range and contingency validation checks (version 5.01, Nantucket ${ }^{\mathrm{TM}}$ Corporation, 1991, S.F., California). Descriptive analysis was run in SPSS for Windows (version 10.1.4; SPSS Inc, Chicago, U.S.A., 2000). Regression models were adjusted using Stata statistical software (V. 7.0 for Windows, Stata Corp, College Station, Tx, U.S.A. 2001).

\section{Results}

Data on 1363 children and 731 women were obtained; however, the sample size varies for each nutrient because of losses of samples or unrecoverable results (Table I). The sample size for pregnant women was insufficient to furnish reliable conclusions, thus they are not presented in this analysis.

\section{Children under 12 years of age}

Iron status. The prevalence of overt iron deficiency (PTS $<16 \%$ ) at the national level was highest in infants 12 to 24 months of age $(66.6 \%)$. Although the prevalence of iron deficiency declined progressively with age, it remained very high in school-age children (33.8-38.7\%). Prevalence of iron deficiency was higher in rural than urban children, differences were of at least 10 percent points, except at 11 years of age. At that age a surge in the prevalence of iron deficiency in urban children changed the direction of the difference in prevalence relative to rural children $(p<0.05)$. Urban children were able to reduce their prevalence of iron deficiency in 33\% at three years of age, while rural reduced it in only 16\% (Table III). The North $(73.1 \%)$, center $(87 \%)$, and South $(75 \%)$ regions had the highest prevalence in infants younger than two years. Children from the North and center reduced their prevalence of iron deficiency by more than 30 percentage points by three years of age, while those from the South did so by only 10 percent points at the same age.

In a logistic regression analysis the likelihood of being iron deficient was not affected by SEL, Indigenous ethnicity, being beneficiary of food assistance programmes, dietary intakes of cereals, meat or leguminous (Table V).

\section{Zinc stat us}

The prevalence of low serum zinc levels was highest in children under of 24 months of age (33.9\%) and it declined progressively with age, maintaining a plateau during the school age (19.3-24.4\%) (Table II). The global prevalence of low serum zinc levels in rural children under 12 years of age $(40.0 \%)$ was twice that of their urban counterparts (18.2\%); however, the opposite occurred in children under of 24 months of age ( 24.7 vs. $36.6 \%$, respectively) (Table III). The highest prevalence of low serum zinc levels after two years of age occurred in the South region, at all ages (20.9$51.7 \%$ ), while the lowest corresponded to the North region $(5.5-14.2 \%)$.

Logistic regression showed that the likelihood of having low serum zinc levels was lower as SEL increased $(\mathrm{OR}=0.44, p=0.001)$, (Table V).

\section{lodide status}

The prevalence of urine iodide concentrations compatible with severe iodide deficiency were not detected in 
TABLE I

SOME DESCRIPTIVE DATA ON THE SAMPLE OF CHILDREN UNDER OF 12 AND WOMEN 12-49 YeARS OF AGE. National Nutrition Survey, Mexico, 1999

Characteristics
Sample

n \begin{tabular}{cl} 
Expanded (Thousand) & \\
\hline $\mathrm{n}$ & $\%$
\end{tabular}

N on-pregnant women 12- 49 years of age

BMI (kg/height ${ }^{2}$ )

\begin{tabular}{cccc}
$<18.5$ & 16 & 112.8 & 1.6 \\
\hline $18.5-24.9$ & 314 & 3175.5 & 44.3 \\
\hline $25-29.9$ & 221 & 2438.5 & 20.0 \\
\hline$\geq 30$ & 161 & 1443.1 & 31.2 \\
\hline $\begin{array}{c}\text { SEL** } \\
\text { Low }\end{array}$ & 252 & 2289.1 & 30.2 \\
\hline Medium & 234 & 2211.1 & 38.6 \\
\hline High & 245 & 2826.7 & 73.7 \\
\hline Residence & & & 26.3 \\
\hline Urban & 452 & 5397.3 & $28.9 \pm 9.4^{*}$ \\
\hline Rural & 279 & 1929.5 &
\end{tabular}

Children under of 12 years of age

Gender

\begin{tabular}{|c|c|c|c|}
\hline Male & 705 & 8195.4 & 52.8 \\
\hline Female & 658 & 7327.4 & 47.2 \\
\hline \multicolumn{4}{|l|}{ Age group } \\
\hline $0.5-2$ & 48 & 1092.1 & 7.0 \\
\hline $3-4$ & 176 & 4282.4 & 27.6 \\
\hline $5-6$ & 263 & 2227.8 & 14.4 \\
\hline $7-8$ & 354 & 2992.3 & 19.3 \\
\hline $9-10$ & 352 & 3439.5 & 22.2 \\
\hline 11 & 170 & 1488.8 & 9.6 \\
\hline \multicolumn{4}{|l|}{ Residence } \\
\hline Rural & 631 & 4847.4 & 31.2 \\
\hline Urban & 733 & 10675.4 & 68.8 \\
\hline \multicolumn{4}{|l|}{ SEL** } \\
\hline Low & 523 & 5824.1 & 37.5 \\
\hline Medium & 332 & 3860.3 & 24.9 \\
\hline High & 508 & 5838.5 & 37.6 \\
\hline
\end{tabular}

*Mean \pm SD.

** Socioeconomic status was categorized into three levels, based on principal component analysis of household possessions and characteristics

children under 5 years of age, and the prevalence was $0.5 \%$ in school-age children. The remaining children in the sample had iodide concentrations either within the normal range or indicative of a low risk of deficiency. Data were not further disaggregated because of the extremely low prevalence of abnormal values (Table V).

\section{Women 12 to 49 years of age}

Iron status

The prevalence of overt iron deficiency (PTS $<16 \%$ ) at the national level was $40.5 \%$, and was higher in the rural $(51.8 \%)$ than in the urban women $(36.4 \%, p<0.02)$ 


\section{TABLE II}

Prevalence of iron deficiency as by percent transferrin saturation (PTS) $<16 \%$ and of zinc deficiency AS BY SERUM ZINC CONCENTRATIONS $<65$ UG/DL IN CHILDREN UNDER 12 AND NON-PREGNANT WOMEN 12-49 YEARS of age. National Nutrition Survey, Mexico, 1999

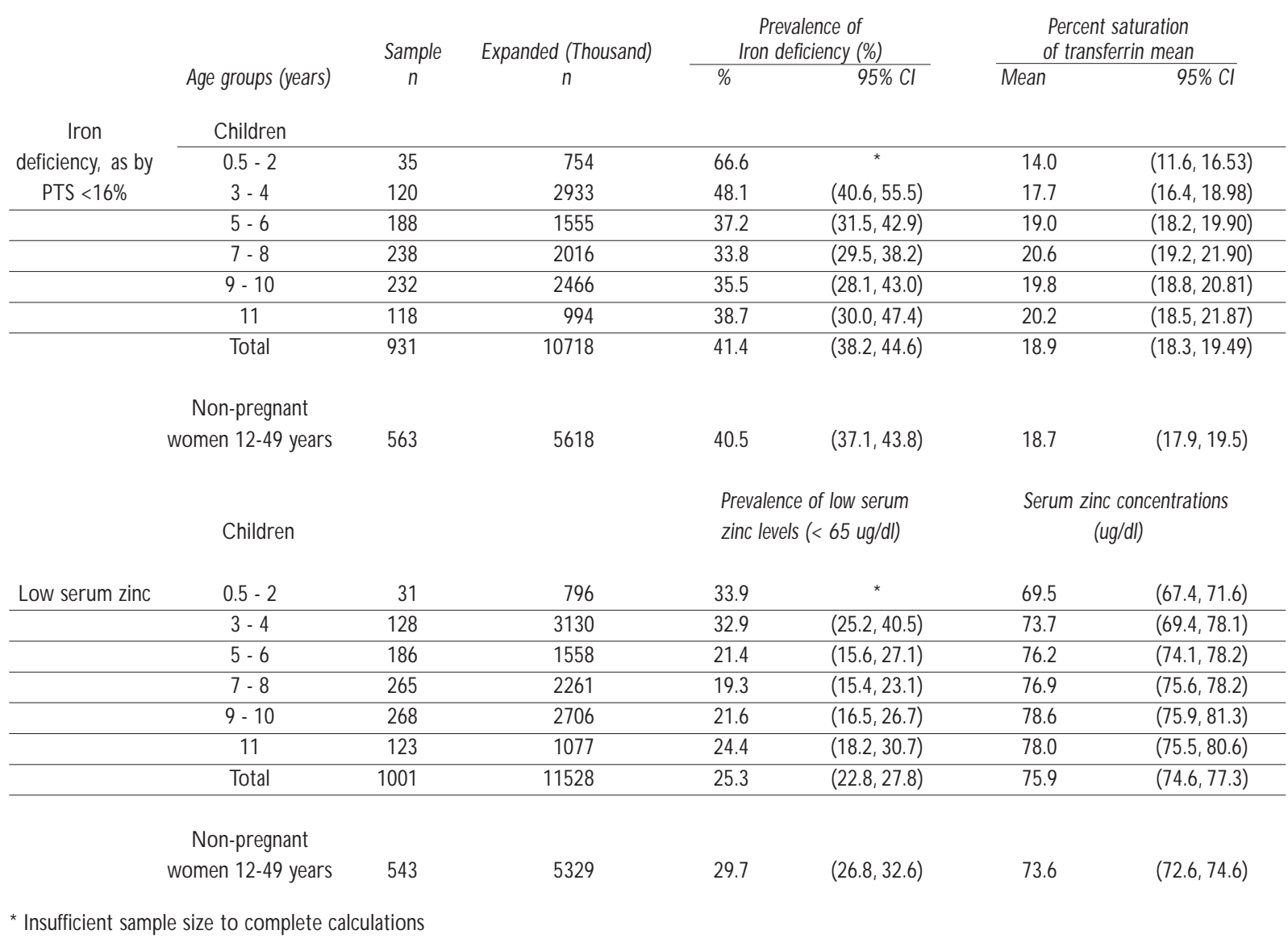

(Table III). The most affected region was the South with a prevalence of $50.9 \%$; nevertheless, the prevalence in the other three regions $(31-36 \%)$ was also high. The prevalence of iron depletion (PTS $>16<20 \%$ ) was about $20 \%$ in all regions, except Mexico City (13\%) The summed prevalence of any form of iron deficiency was more than $70 \%$ in the South and about 50\% in the other regions.

In a logistic regression model the likelihood of having iron deficiency was lower as SEL increased $(\mathrm{OR}=0.77, p=0.04)$ and higher in those with higher cereals intakes $(\mathrm{OR}=1.22, \mathrm{p}=0.01)$. $\mathrm{BMI}$, being beneficiary of food assistance programs, ethnicity, or the intakes of meat, legumes, fruits or vegetables did not affect the risk of being iron deficient (Table V).

\section{Zinc status}

The prevalence of zinc deficiency ( $<65 \mathrm{ug} / \mathrm{dl}$ ) was almost $30 \%$ in the national sample, with no significant salud pública de méxico / vol.45, suplemento 4 de 2003 difference between urban and rural women ( 28.8 vs. $33.9 \%$, respectively) (Table III). The highest prevalence of zinc deficiency corresponded to the South region $(36.4 \%)$ and the lowest to the Mexico City region $(19.2 \%)$. The other two regions were intermediate.

The likelihood of having low serum zinc levels in women was lower as SEL increased (OR=0.74, $p=0.02)$. No association was found with age, BMI, being beneficiary of food assistance programmes or with any of the food groups introduced to the model. (Table V).

\section{Iodide status}

In only one case were the urine concentrations of iodide compatible with severe deficiency. Normal values ( $>100 \mathrm{ug} / \mathrm{l}$ ) or values compatible with mild deficiency (50-99 ug/l) were found in $98 \%$ of the samples. No differences in the prevalence were found between urban and rural women (Table IV). 
TABLE III

Prevalence of iron deficiency as by percent transferrin saturation (PTS) $<16 \%$ AND OF ZINC DEFICIENCY AS BY SERUM ZINC CONCENTRATIONS $<65$ Ug/DL IN CHILDREN UNDER 12 YEARS and non-pregnant women 12-49 years of age. National Nutrition Survey, Mexico, 1999

\begin{tabular}{|c|c|c|c|c|c|c|c|}
\hline & & & & & & & \\
\hline & & & & & & & \\
\hline ars) & $\begin{array}{ll} & \text { Expanded } \\
\text { Sample } & \text { (Thousand) }\end{array}$ & Prevalence & $95 \% \mathrm{Cl}$ & Sample & $\begin{array}{l}\text { Expanded } \\
\text { (Thousand) }\end{array}$ & Prevalence & $95 \%$ \\
\hline
\end{tabular}

Iron deficiency prevalence

Children

\begin{tabular}{lrrrrrrrr}
$0.5-2$ & 19 & 486 & 62.2 & $*$ & 16 & 269 & 74.6 & $*$ \\
\hline $3-4$ & 68 & 2054 & 42.3 & $*$ & 52 & 879 & 61.5 & $*$ \\
\hline $5-6$ & 97 & 1016 & 34.6 & $(28.5,40.6)$ & 91 & 539 & 42.3 & $(30.5,54.1)$ \\
\hline $7-8$ & 129 & 1445 & 31.3 & $(27.3,35.4)$ & 109 & 571 & 40.2 & $(29.4,51.0)$ \\
\hline $9-10$ & 124 & 1628 & 32.4 & $(23.2,41.7)$ & 108 & 838 & 41.7 & $(29.4,53.9)$ \\
\hline 11 & 61 & 686 & 42.1 & $*$ & 57 & 307 & 31.2 & $*$ \\
\hline Total & 498 & 7315 & 38.2 & $(34.8,41.5)$ & 433 & 3403 & 48.3 & $(41.7,54.8)$
\end{tabular}

Non-pregnant wome

$\begin{array}{lllllllll}12-49 \text { years } & 436 & 4134 & 36.4 & (32.8,39.9) & 217 & 1484 & 51.8 & (43.7,59.8)\end{array}$

Low serum zinc prevalence

Children

\begin{tabular}{lrrrrrrrrr}
$0.5-2$ & 19 & 616 & 36.6 & $*$ & 12 & 181 & 24.7 & $*$ \\
\hline $3-4$ & 75 & 2097 & 21.6 & $*$ & 53 & 1033 & 55.8 & $*$ \\
\hline $5-6$ & 98 & 986 & 13.9 & $*$ & 88 & 571 & 34.3 & $*$ \\
\hline $7-8$ & 136 & 1561 & 15.2 & $*$ & 129 & 700 & 28.3 & $(18.3,38.4)$ \\
\hline $9-10$ & 142 & 1783 & 13.6 & $(9.4,17.7)$ & 126 & 923 & 37.1 & $(25.6,487)$ \\
\hline 11 & 63 & 735 & 16.7 & $* *$ & 60 & 341 & 41.1 & $* *$ \\
\hline Total & 533 & 7779 & 18.2 & $(15.9,20.5)$ & 468 & 3749 & 40.0 & $(34.0,45.9)$
\end{tabular}

Non-pregnant women

$\begin{array}{lllllllll}12-49 \text { years } & 322 & 3804 & 28 & (24.7,31.4) & 221 & 1520 & 33.9 & (28.1,31.8)\end{array}$

* Insufficient sample size to complete calculations

\section{Discussion}

Iron deficiency in children. The prevalence of iron deficiency was very high in all children but particularly in those under 24 months of age. Iron deficiency was $25 \%$ higher than the prevalence of anemia $(50 \%)$ reported for the same infants from the NNS-99. ${ }^{24}$ Plausible explanations for such a high prevalence of iron deficiency in this age group include: a) There is a high prevalence of iron deficiency in women of reproductive age from the same households herein reported, particularly those that were pregnant. The latter may lead to development of limited fetal iron stores of their offspring. b) Even milk from well-nourished mothers does not meet the infant's iron requirements after the first few months of life; iron status of the infant then relies only on preexisting stores. c) Dietary transition from lactation to the family diet frequently implies weaning children with foods of low energy and iron densities. ${ }^{25}$ Thus, the higher risk for iron deficiency occurs in the first years of life when children are less able to eat a diet with a larger content of iron. In support of this notion we observed that although the prevalence of iron deficiency declined in both rural and urban infants, rural infants reduced their prevalence of iron deficiency two years after their urban counterparts. Such differences might be attributed to differences in the timing and quality of weaning diets between the two groups. Iron deficiency in women of childbearing age. The prevalence of iron deficiency in salud pública de méxico / vol.45, suplemento 4 de 2003 
TABLE IV

Prevalence of Iodide deficiency as indicated by the EXCRETION OF URINARY IODIDE IN CHILDREN UNDER 12 YEARS of age. National Nutrition Survey, Mexico, 1999

\begin{tabular}{|c|c|c|c|c|c|}
\hline \multirow{3}{*}{$\begin{array}{c}\text { Urinary } \\
\text { iodide } \\
\text { ug/l }\end{array}$} & \multicolumn{4}{|c|}{ Children (age in years) } & \multirow{3}{*}{$\begin{array}{c}\text { Total } \\
\mathrm{n}\end{array}$} \\
\hline & \multicolumn{2}{|c|}{$0.5-4$} & \multicolumn{2}{|c|}{$5-12$} & \\
\hline & $\mathrm{n}$ & $\%$ & $\mathrm{n}$ & $\%$ & \\
\hline$>100$ & 14 & 83 & 529 & 91.5 & 543 \\
\hline $50-99$ & 4 & 17 & 37 & 5.9 & 41 \\
\hline $20-49$ & 0 & 0 & 18 & 2.0 & 18 \\
\hline$<20$ & 0 & 0 & 1 & 0.5 & 1 \\
\hline Total & 18 & 100 & 585 & 100 & 600 \\
\hline
\end{tabular}

N on-pregnant women $12-49$ years of age

\begin{tabular}{rrr}
$>100$ & 560 & 92.9 \\
\hline $50-99$ & 35 & 5.3 \\
\hline $20-49$ & 10 & 1.7 \\
\hline$<20$ & 1 & 0.2 \\
\hline Total & 603 & 100
\end{tabular}

women was high in general but some distinctions are in order. It was higher in rural residents and in those living in the poorest (South) region of the country. Iron deficiency was as high in school-age children as in women suggesting that they share common dietary insufficiencies. Higher daily intakes of cereals represented a risk for iron deficiency too, suggesting that they may interfere with the availability of iron. Corn and corn products were the most frequently eaten food by this population, referred, both, as grams per day or as kcal per day. ${ }^{26}$ Corn is known to be one of the cereals with the highest content of phytic acid, a potent inhibitor of the intestinal absorption of iron and other divalent metals. Thus, it is very plausible that the negative association between the intake of cereals and iron status of this population may be explained by the higher intake of corn phytates.

Nutritional interventions aiming to improve the iron status of young children and women of childbearing age are urgent in order to reduce the deleterious effects of iron deficiency anemia and other forms of iron deficiency on growth, ${ }^{27}$ mental development, ${ }^{28} \mathrm{im}$ mune ability to combat infections, ${ }^{29}$ and work capacity ${ }^{30}$

\section{Zinc nutritional status}

The lower cut-off value, relative to those most frequently accepted ${ }^{15}$ was chosen for this study based on the recent recommendations of the IZINCG for non-fasting serum samples, as was the case for the serum sam- ples from this survey. ${ }^{16}$ In this study, we demonstrated that the prevalence of low serum zinc affected more to children living in the poorest regions and to those of the lower SEL.The primary cause of zinc deficiency is believed to be the inadequate intake of dietary zinc..$^{16,31}$ It is difficult to meet dietary requirements for zinc in populations where a large proportion of dietary intake is derived from cereals such as corn (maize) and very little food from animal sources.

Zinc deficiency has profound and far-reaching effects on the health and well being of humans. There is a large body of convincing evidence linking zinc deficiency to childhood growth stunting, ${ }^{32}$ increased prevalence of common childhood infections such as diarrhea and pneumonia, ${ }^{33}$ reduced appetite among children, ${ }^{34}$ impaired neurobehavioral function, ${ }^{35,36}$ delayed sexual maturation among adolescents, ${ }^{37}$ poor pregnancy outcomes including low birth weight, preterm deliveries, maternal delivery complications, ${ }^{38}$ and impaired immune function of the neonate, ${ }^{39}$ and increased risk of infant mortality among low birth weight infants. ${ }^{40}$ Despite these far reaching consequences, much remains to be learned about efficacious methods to prevent zinc deficiency. Women of childbearing age may be at even higher risk of zinc deficiency in comparison to other groups (e.g. adult men) due to the higher requirements for zinc during fetal development and lactation. ${ }^{41}$

\section{lodide status}

Given the results presented, the prevalence of iodide deficiency is negligible in both, women and children. Distribution of abnormal results was so scattered that no remarks can be made relating to geographical distribution. We recognize that the scope of our study does not allow us to distinguish micro regions where iodide deficiency might be still high. Table salt iodination is the most ancient public nutrition intervention in Mexico. Salt iodination has been mandatory by law for more than 50 years; thus, it is not surprising to find such a low prevalence of low urinary iodide levels. A note of caution is in order, however, as we checked on the iodide level of table salt and found (data not shown) that industrially refined salt, but none of the other forms available on the market complied with the required levels of iodide.

In summary the prevalence of iron and zinc deficiency is very high in women of childbearing age and children, especially those under two years of age. The evidence indicates that poverty is the main underling cause of iron and zinc deficiencies. The association between some dietary factors suggests that the iron deficiencies are related to low intake of the most bio- 


\section{TABLE V}

LOGISTIC REGRESSION MODELS OF IRON AND ZINC STATUS ON POTENTIALLY PREDICTIVE VAriables in Children under 12 years of age. National Nutrition SurVey, Mexico, 1999

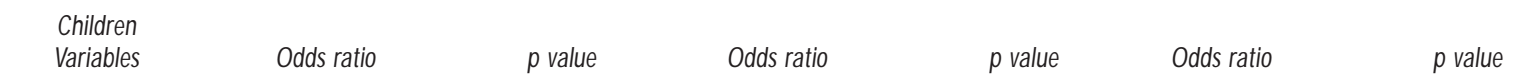

Iron (PTS)

$\mathrm{N}=670$

Age (months)

SEL* $\quad 0.79$

BFAP ${ }^{\ddagger} \quad 0.99$

Indigenous ethnicity

Cereals $(100 \mathrm{~g} / \mathrm{d}) \quad 0.90$

Meat $(100 \mathrm{~g} / \mathrm{d}) \quad 0.86$

Legumes $(100 \mathrm{~g} / \mathrm{d}) \quad 0.85$

Zinc

$\mathrm{N}=726$

Age (months)

SEL $\quad 0.44$

BFAP 1.12

Indigenous ethnicity

Cereals (100g/d)

Meat $(100 \mathrm{~g} / \mathrm{d})$

Legumes $(100 \mathrm{~g} / \mathrm{d})$

Model 1

Model 2

Model 3

Model 1

Model 2

Model 3

0.20
0.45
1.13
0.62
0.93
0.26
0.69

0.10

0.001

0.64

0.82

0.62

0.62

Women
Variables Odds ratio $\quad p$ value $\quad$ Odds ratio $\quad p$ value $\quad$ Odds ratio $p$ value

Iron (PTS)

Model 1

Model 2

Model 3

$n=553$

Age (years)

$\begin{array}{lll}1.008 & & 0.54 \\ 1.011 & & 0.58 \\ 0.815 & 0.11 & \\ 0.880 & 0.64 & \\ 0.961 & & 0.93 \\ 1.228 & & 0.01 \\ 1.126 & & 0.44 \\ 0.965 & & 0.83\end{array}$

Body Mass Index

SEL*

BFAP ${ }^{\ddagger}$

Indigenous ethnicity ${ }^{\S}$

Cereals (100g/d)

Meat $(100 \mathrm{~g} / \mathrm{d})$

$\begin{array}{ll}0.88 & 0.24 \\ 0.73 & 0.31 \\ 0.86 & 0.67\end{array}$

Leguminous $(100 \mathrm{~g} / \mathrm{d})$

Zinc

Model 1

$\begin{array}{ll}1.03 & 0.68 \\ 1.753 & 0.16 \\ 1.277 & 0.63\end{array}$

$\mathrm{n}=534$

\begin{tabular}{lcccccc} 
Age (years) & 1.018 & 0.16 & 1.018 & 0.16 & & \\
\hline Body Mass Index & 0.988 & 0.55 & 0.988 & 0.54 & & \\
\hline SEL 0.747 & 0.03 & 0.742 & 0.02 & & & \\
\hline BFAP 1.714 & 0.07 & 1.732 & 0.06 & 0.97 & 1.097 & 0.19 \\
\hline Indigenous ethnicity & 0.991 & 0.98 & 1.015 & & 0.963 & 0.68 \\
\hline Cereals (100g/d) & 1.043 & 0.56 & & 0.958 & 0.85
\end{tabular}

* Socioeconomic status is a continuous variable, based on principal component analysis of household possessions and characteristics (mean $=0, S D=1$ )

₹ BFAP (beneficiary of food assistance programs). Belongs to a family receiving corn tortillas or milk at subsidized prices, or free food baskets (Beneficiary= 1 and not beneficiary=0)

$\S$ Indigenous ethnicity was defined when a woman $12-49 y$ in the household spoke a native language ( $1=y e s$ and $0=n 0)$ 
available forms of the mineral, and to the intake of dietary iron and zinc inhibitors. Aggressive interventions are imperative to correct iron and zinc deficiencies and by so doing avoid their deleterious effects .

\section{References}

1. Commission on the N utrition Challenge of the $21^{\text {st }}$ Century. Ending malnutrition by 2020:An agenda for change in the millennium. Final report to the ACC/SCN Food N utr Bull 2000;21: (v3) 2. Rivera JA, Martorell R, Ruel MT, Habicht J-P, Hass JD. N utritional supplementation during the preschool years influences body size and composition of Guatemalan adolescents. J N utr 1995;125:1068S-1077S. 3. Shankar AH, Prasad AS. Zinc and immune function:The biological basis of altered resistance to infection. Am J C lin N utr 1998; 68:447S-463S. 4. Sepúlveda-A mor J, Lezana MA, Tapia-C onyer,Valdespino JL, Madrigal H, Kumate J. Estado nutricional de prescolares y mujeres en México: resultados de una encuesta probabilística nacional. G ac Med Mex 1990; 126:207-224.

5. Anonimous. Segundo Censo $\mathrm{N}$ acional de talla. En niños de primer grado de primaria. Informe técnico ejecutivo. Sistema $\mathrm{N}$ acional para el desarrollo integral de la familia, México D.F., 1996.

6. Rivera J, Shamah T,Villalpando S, G onzález T, Hernández B, Sepúlveda J, ed. Encuesta $\mathrm{N}$ acional de $\mathrm{N}$ utrición 1999. Estado N utricio de Niños y Mujeres en México. Cuernavaca, Morelos, México. Instituto N acional de Salud Pública, 2001.

7. Rivera J, Bourges H, A rroyo P, Casanueva E, C havez A, Halhalali A, et al. Deficiencia de micronutrimentos. En: De la Fuente JR, Sepúlveda J, comp. Diez problemas relevantes de salud pública en México. México, D.F.: Fondo de Cultura Económica, 1999:15-57.

8. Rosado JL, Bourges H, SainT-Martin B. D eficiencias de vitaminas y minerales en México. Una revisión crítica del estado de la información: I. Deficiencia de minerales. Salud Publica Mex 1995; 37:13-19.

9. Loria A, Sánchez L,A rroyo E, Cordourier E, Piedras J, C asanueva E. $\mathrm{N}$ utritional anemia.VIII Hemoglobin and plasma iron in infants treated perinatally with iron. N utr Rep Internat 1979; 19:451-62

10. Instituto $N$ acional de Salud Pública. Encuesta $N$ acional de N utrición 1999. Tomo I. N iños menores de 5 años. Cuernavaca, Morelos: IN SP, 2000:14-24.

11. Henry JB. C linical diagnosis and management by laboratory methods. Philadelphia (PA):W .B. Saunders 1991.

12. N ational Committee for Clinical Laboratory Standards. Method comparison and bias estimation using patients serum samples:Tentative guideline.Villanova, (PA): N C CLS, 1992. Publication EP9-T.

13. Herbert V. The Herman Award Lecture. N utrition Science as a continually unfolding story:The Folate and Vitamin B12 paradigm. Am J

C lin N utr 1986; 46: 387-400.

14. Makino T,Takahara K. Direct determination of plasma copper and zinc in infants by atomic absorption with discreet nebulization. C lin Chem 1981; 27:1445-1449.

15. Gibson RS. Zinc nutrition in developing countries. N utr Res Rev 1994; 7: 151-173.

16. D unn JT, Crutenfield HE, Gutekunst R, D unn AD. Methods for measuring iodine in urine. ICCIDD/Fondo Internacional de Ayuda a la Infancia/W orld Health O rganization,W ashington D.C ., 1993.

17. Indicadores para evaluar los transtornos por carencia de yodo y su control mediante la yodación de la sal. IC CID D/O rganización Mundial de la Salud/O rganización Panamericana de la Salud/Fondo Internacional de Ayuda a la Infancia, D ocumento técnico. W HO /N ut/94.6, Geneve, Switz, 1994

18. Morales J, BabinskyV, Bourges H, C amacho ME. Tablas de Composición de Alimentos Mexicanos del Instituto $\mathrm{N}$ acional de Ciencias Médicas y N utrición "Salvador Zubirán", México, D.F.: IN MN SZ 2000. 19. Muñoz M, Chávez A, Pérez-Gil F, Roldán JA, Hernández S, Ledesma $J A$, et al.Tablas de valor nutritivo de los alimentos de mayor consumo en México. México, D.F: Editorial Pax, México, 1996.
20. Database for Standard Reference. US D epartment of A griculture, A gricultural Research Service. USDA N utrient, Release 13. N utrient Data Laboratory, 1999.

21. Scherz H, Senser F. Der zusament setzung der Lebensmittel, $N$ ährwert - Tabellen/on behalf of the Bundesministerium für Ernährung, Land wirts shaft und Forsten, Bonn, ed. , Stuttgart: Medpharm Scientific (Pub) and CRC Press, London UK, 2000.

22. Instituto de Nutrición de Centro América y Panamá.Tabla de composición de alimentos. Guatemala, C A: IN CAP, 1994.

23.Anonimous.W orld Food Dietary Assessment System.V 2.0, University of California, Berkeley, 1997.

24.Villalpando S, Shamah-Levy T, Ramírez-Silva Cl, Mejía-Rodríguez F, Rivera JA. Prevalence of anemia in children 1 to 12 years of age. Results of a nationwide probabilistic survey in Mexico. Salud Publica Mex 2003;45 suppl 4:S490-\$498.

25.A nonimous. Complementary feeding of young children in developing countries:A review of current scientific knowledge. Geneva:W HO , 1998; W HO /N UT/98.1.

26. Avila A, Shamah T, C havez A. Encuesta N acional de A limentación y Nutrición en el Medio Rural 1996.Vol 1. Resultados por Entidad. México, D.F: IN N SZ: 1998.

27. Rivera JA, Martorell R, Ruel MT, Habicht J-P, Hass JD. N utritional supplementation during the preschool years influences body size and composition of Guatemalan adolescents. J N utr 1995;125:1068S-1077S. 28. Pollitt E, Gorman K, Engle PL, Rivera JA, Martorell R. N utrition in early life and fulfillment of intellectual potential.J. N utr. 1995;125:1111S-1118S. 29. Chandra RK. N utrition, immunity and infection: Present knowledge and future directions. Lancet 1983; 1:688-693.

30. Haas JD, Murdoch S, Rivera J, Martorell R. Early nutrition and later physical work capacity. N utr Rev. 1996; 54:S41-S48.

31. Brown KH,W uehler SE, Peerson JM. The importance of zinc in human nutrition and estimation of the global prevalence of zinc deficiency. Food N utr Bull 2001;22:113-125.

32. Brown KH, Peerson JM, Allen LH, Rivera J. Effect of supplemental zinc on the growth and serum zinc concentrations of pre-pubertal children: A meta-analysis of randomized, controlled trials. Am J C lin $N$ utr 2002;75:1062-1071.

33. Zinc Investigators' Collaborative Group. Prevention of diarrhea and pneumonia by zinc supplementation in children in developing countries: pooled analysis of randomized controlled trials.J Pediatr 1999;135:689-697. 34. Krebs N F, Hambidge KM, W alravens PA. Increased food intake of young children receiving a zinc supplement. Am J D is C hild 1994;138:270-273

35. Penland JG, Sandstead HH, Alcock N W, et al. A preliminary report: Effects of zinc and micronutrient repletion on growth and neuropsychological function of urban Chinese children. J Am Coll N utr 1997;16:268-272.

36. Bentley ME, Caulfield LE, Ram M, Santizo MC, Hurtado E, Rivera JA, Ruel MT, Brown KH. Zinc supplementation affects the activity patterns of rural Guatemalan infants. J N utr 1997;127:1333-1338.

37. Ronaghy HA, Reinhold JG, Mahloudji M, G havami P, Fox MR, Halsted JA. Zinc supplementation of malnourished schoolboys in Iran: Increased growth and other effects. Am J C lin N utr 1974;27:112-121.

38. King JC. D eterminants of maternal zinc status during pregnancy.Am J C lin N utr (2000) 71: 1334S-1343S.

39. 0 sendarp SJM, van Raaij JMA, D armstadt GL, Baqui AH, Hautvast JG, Fuchs $\mathrm{G}$. Z Zinc supplementation during pregnancy and effects on growth and morbidity in low birthweight infants: a randomized placebo controlled trial. Lancet 2001:357:1080-1085.

40. Sazawal S, Black RE, Menon VP, D inghra P, C aulfield LE, D hingra U, et al. Zinc supplementation in infants born small for gestational age reduces mortality: a prospective, randomized, controlled trial. Pediatr 2001;108:1280-1286.

41. Food and Nutrition Board and the Institute of Medicine. Dietary reference intakes for vitamin A, vitamin $\mathrm{K}$, boron, chromium, copper, iodine, iron, manganese, molybdenum, nickel, silicon, vanadium and zinc. W ashington, DC: N ational A cademy Press, 2001. 